\title{
Using Rosetta Stone Media Through the Dynamic Immersion Method to Improve Vocabulary Mastery for Junior High School Students
}

\author{
Nursaima Harahap \\ Department of English Education \\ University of Graha Nusantara Padangsidimpuan, Indonesia \\ nursaima20okt@gmail.com \\ Yulia Rizki Ramadhani \\ Department of English Education \\ University of Graha Nusantara Padangsidimpuan, Indonesia
}

\author{
Siti Meutia Sari \\ Department of English Education \\ University of Graha Nusantara Padangsidimpuan, Indonesia
}

\author{
Rizka Safriyani \\ Department of English Education \\ UIN Sunan Ampel, Surabaya, Indonesia \\ rizkasafriani@uinsby.ac.id
}

\author{
Rosni Harahap \\ Department of English Education \\ University of Graha Nusantara Padangsidimpuan, Indonesia \\ Corresponding e-mail: nursaima20okt@gmail.com
}

\begin{abstract}
The purpose of this study is to find out the answers to research problems. For more specific the objectives of this study are 1) to increase the vocabulary of students' English vocabulary using Rosetta Stone media and applying the Dynamic Immersion method at the seventh-grade students of SMP N 3 Padangsidimpuan. ; 2) To find out the effectiveness of rosetta stone software as media in teaching student's vocabulary at the seventh-grade students of SMP N 3 Padangsidimpuan. Quasiexperimental methods are methods used in evaluations to obtain information. This research is conducted on the seventh-grade students of SMP Negeri 3 Padangsidimpuan consisting of seven classes involving two classes of respondents which areas the experimental groups and control groups. The experimental group was treated by using Rosetta Stone learning media, while the control group was not treated. Based on the result, the writer got a mean of pre-test of the experimental group was 50,91and pretest of the control group was 49,39. The score post-test of experimental was 74,24 and control group was 63,64 .The result of the t-test is higher than t-table; 4,93 > 1,99. It means that the achievement of students (taught by Rosetta stone) as media in vocabulary mastery is better than those without taught Rosetta stone.
\end{abstract}

Keywords: rosetta stone, visual, dynamic immersion, learning media, vocabulary

\section{INTRODUCTION}

English is an international language that is used to communicate among people all over the world. English is so widely spoken; it has often referred to as a world language, the lingua franca of the modern era and while is not an official language in most countries, it is currently the language most often taught as a foreign language in Indonesia, English is considered as a first foreign language and compulsory subject to be taught in secondary schools.

The students' vocabulary was low, the difficulty is caused by many factors varying from the difference of type between the second language learners first language and the second language they are learning and their lack of vocabulary, the teacher still used a conventional method that makes students get bored and lack of motivation in learning. The teacher should use varieties of strategies in teaching vocabulary. One of the strategies that can be used by the teacher is using media to support the teaching-learning process.

The use of media influences the students' interest in learning English. Rosetta Stone Software is offered as one of interesting and one of the alternative media to be used to improve student's vocabulary mastery. Rosetta Stone software uses a combination of pictures, text, and sound techniques by continuously improving the difficulty level, compensating for student progress and this software has a lot of features that can 
be used for Pronunciation, Listening, Reading, Writing, Vocabulary, or Grammar. Rosetta Stone calls it the "Dynamic Immersion method". The goal is to teach a language like the first language we learn. Using Systematic and Integrated Learning System. This media can be one of an alternative way for students to learn English more fun and enhance their motivation in learning English.

Based on the background description above, it can be identified variously the following problems:

1) English is a difficult subject to be learned caused their lack of vocabulary, they found that the varieties of words in English and the difference of written and spoken.

2) The teacher was still using a conventional method that makes students get bored and lack of motivation in learning

3) The Rosetta Stone media has never been used in teaching English, especially vocabulary.

Based on the background of the research, there are two objectives of this research is to find out the answers to research problems. For more specific the objectives of this study are 1) to increase the students' English vocabulary mastery using Rosetta Stone media and applying the Dynamic Immersion method at the seventh-grade students of SMP N 3 Padangsidimpua, and 2) to find out the effectiveness of rosetta stone software as media in teaching student's vocabulary at the seventh-grade students of SMP N 3 Padangsidimpuan.

\section{METHOD}

This research conducted to students of seventh grade of SMP N 3 Padangsidimpuan within held in even semester of 2018/2019 academic year. This research used purposive sampling, for the sample the writer takes two classes of seventh grade of SMP 3 Padangsidimpuan, the first class is 33 students as experimental class and 33 students of the second as a controlled class.

The method of this study is quasi-experimental, the experiment will conduct in two groups. They are experimental and control group. This study will use a pretest-posttest group design with two times observations, the first test will be given before treatment, and the second test will be given after treatment.

This research has two variables they are independent variables and dependent variable, namely: 1). the independent variable is the process of teaching and learning using Rosetta Stone as media, and 2) The dependent variable is the learning achievement vocabulary mastery.

The instrument used for collecting the data is a vocabulary test. It divided into two tests, pre-test and post-test. The test consists of 25 questions, they are multiple-choice and fill in the blank.

The writer used the quantitative data analysis. This study would be successful when there is an increase in students' vocabulary mastery. The result of pre-test and post-test would be analyzed to prove the hypothesis by t-test formula using the SPSS as a calculation tool.
Then, the result is consulted with t-table. If the calculation is more than / same with t- table, it means that there is a significant difference between the two groups. If the calculation is less than t-table, it means that there is no significant difference between them.

\section{FINDINGS AND DISCUSSION}

This research aims to know the using Rosetta Stone software as media in teaching student' vocabulary at seventhgrade students of SMP N 3 Padangsidimpuan. Before the writer doing the study, first, the writer did pre-test. The mean score of students in the control class and experimental class before treatment can be seen in the table below:

\begin{tabular}{|l|c|c|c|c|}
\multicolumn{1}{c|}{ TABLE I. } & \multicolumn{5}{c|}{ THE RESULT OF PRE-TEST } \\
\hline Class & N & Mean & $\begin{array}{c}\text { Std. } \\
\text { Deviati } \\
\text { on }\end{array}$ & $\begin{array}{c}\text { Std. } \\
\text { Error } \\
\text { Mean }\end{array}$ \\
\hline control class & 33 & 49,39 & 10,213 & 1,778 \\
\hline experimental class & 33 & 50,91 & 8,879 & 1,546 \\
\hline
\end{tabular}

From the calculation above, the writer concluded that the score of mean pre-test between experimental group and control group is not so different, because the mean of pre-test of the experimental group (50.91) is higher than or similar with the mean of pre-test of the control group (49.39) where $\mathrm{Ma} \geq \mathrm{Mb}$; both the groups have equal ability.

After getting treatments, both of the groups got the posttest. It is used to find the result of the experiment. The posttest was calculated with the t-test formula.

The mean score of students in the control class and experimental class after treatment can be seen in the table below :

TABLE II. THE RESULT OF POST-TEST

\begin{tabular}{|l|c|c|c|c|}
\hline \multicolumn{1}{|c|}{ Class } & N & Mean & $\begin{array}{c}\text { Std. } \\
\text { Deviati } \\
\text { on }\end{array}$ & $\begin{array}{c}\text { Std. } \\
\text { Error } \\
\text { Mean }\end{array}$ \\
\hline control class & 33 & 63,64 & 9,460 & 1,647 \\
\hline experimental class & 33 & 74,24 & 7,918 & 1,378 \\
\hline
\end{tabular}

From the calculation above, the writer concludes that the score of mean post-test between experimental group and control group is any difference because the mean of pre-test of the experimental group (74.24) is higher than the mean of post-test of the control group (63.64) where $\mathrm{Ma}>\mathrm{Mb}$. 
TABLE III. THE RESULT T-TEST OF POST TEST

\begin{tabular}{|c|c|c|c|c|c|c|}
\hline & $\begin{array}{c}\text { Levene's Test } \\
\text { for Equality of } \\
\text { Variances }\end{array}$ & \multicolumn{4}{|c|}{ t-test for Equality of Means } \\
\hline & $\mathrm{F}$ & Sig. & $\mathrm{t}$ & $\mathrm{df}$ & $\begin{array}{c}\text { Sig. } \\
(2- \\
\text { taile } \\
\mathrm{d})\end{array}$ & $\begin{array}{c}\text { Mean } \\
\text { Differen } \\
\text { ce }\end{array}$ \\
\hline $\begin{array}{c}\text { Equal } \\
\text { variances } \\
\text { assumed }\end{array}$ & 1,853 &, 178 & $-4,939$ & 64 &, 000 & $-10,606$ \\
\hline $\begin{array}{c}\text { Equal } \\
\text { variances } \\
\text { not } \\
\text { assumed }\end{array}$ & & & $-4,939$ & 62,075 &, 000 & $-10,606$ \\
\hline
\end{tabular}

Based on the table above, it is known that sig. (2-tailed) of $0.00<0.05$, it can be concluded that there are differences in the average student learning outcomes in the control class and the experimental class after treatment. The calculation result of t-test is 4,93 with $\mathrm{Df}=\mathrm{na}+\mathrm{nb}-2$, Df $=64$, level of signification $5 \%$ and $t$-table $=1.99$. The result of the t-test is $4,93>1,99$. So, the statistical t-test is greater than t-table. Based on the result, it means that there is a significant difference in post-test scores between the experimental group and the control group.

As calculated above, the score post-test of t-test was 4,93 while the $t$ table was 1,99 . So, the score post-test of t-test was higher than the $t$ table. Based on the study hypothesis rule, If the score of t-test was equal to or higher than the score of $t$ table, the null hypothesis (Ho) would be rejected and the alternative hypothesis ( $\mathrm{Ha}$ ) would be accepted. Conversely, If the score of t-test was smaller than the value of t-table, the null hypothesis (Ho ) would be accepted and the alternative hypothesis (Ha) would be rejected. So, it could be inferred that this study agreed that using rosetta stone software was effective as media in teaching students' vocabulary mastery to the seventh-grade students of SMPN 3 Padangsidimpuan.

\section{CONCLUSION}

The results of the study showed that the mean posttest of vocabulary mastery of experimental group is higher than the posttest results of control group students. From the mean data obtained, it can be seen that there are significant differences in vocabulary learning at seventh-grade students of SMP N 3 Padangsidimpuan between those taught by using Rosetta Stone media and those who don't teach by using Rosetta Stone media.

Giving treatment using Rosetta Stone media at each meeting in the experimental class produced posttest data which is different from the control class. The use of Rosetta Stone media is one of the learning strategies that are fun because students are invited to learn with media that is easy to understand and in simple language but the contains aspects that are appropriate to the learning objectives, as attached in the lesson plan (RPP).
Teaching students' vocabulary by using Rosetta Stone media contains a contextual approach that makes students more active and enthusiastic. This is a fun learning strategy because students are invited to learn with fun media. This can encourage students to be active in learning and make students more enthusiastic in learning. Thus it can be said that the vocabulary learning of seventh-grade students of SMP N 3 Padangsidimpuan using Rosetta Stone media is more effective than without using Rosetta Stone media.

\section{REFERENCES}

[1] Godwin-Jones, Robert. Emerging Technologies: Tools and Trends in Self-Paced Language Instruction. Language Learning \& Technology, 11(2), pp.10-17, 2007.

[2] Hanif. Using Rosetta Stone Software As Media In Teaching English Vocabulary.p 31-32, 2015.

[3] Hatch, Evelyn and Brown, Cheryl. Vocabulary, Semantics, and Language Education. Cambridge: Cambridge University Press, 1995.

[4] Maria,f. Teaching English As A Foreign Language In Indonesia.p.10, 2005.

[5] Renandya, W.A.,\& Richards, J.C. Methodology in Language Teaching.New York: Cambridge University Press, 2002.

[6] Rockman, et.al.S. An effectiveness study of the Rosetta Stone Spanish language solution, 2009. Rosetta Stone Evaluation Report resources.rosettastone.com/.../Rockman-EvaluationReport.pdf.

[7] Schmitt, Norbert and Mc Carthy. Vocabulary, Description, Acquisition and Pedagogy. Cambridge: Cambridge University Press, 2000.

[8] Sudjana, Djuju. Evaluasi Pendidikan Luar Sekolah : Untuk Pendidikan Nonformal dan Pengembangan Sumber Daya Manusia. Bandung: PT. Remaja Rosdakarya, 2008.

[9] Thornbury, Scott. How to Teach Vocabulary. London: Longman, 2004.

[10] Ur, Penny. A Course in Language Teaching, Practice and Theory. Cambridge: Cambridge University Press, 1996. 